\title{
IMPLEMENTATION OF PROFILE MATCHING METHOD IN ASSESSMENT OF EMPLOYEE PERFORMANCE IN DIRECTORATE GENERAL OF OIL AND GAS
}

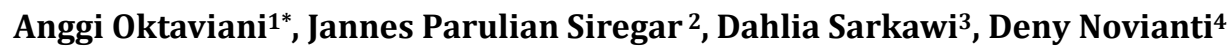 \\ Informatics Engineering, Information Systems \\ STMIK Nusa Mandiri, Jakarta, Indonesia \\ www.nusamandiri.ac.id \\ anggi.aov@nusamandiri.ac.id ,11190148@nusamandiri.ac.id \\ Office administration, Information Systems \\ Universitas Bina Sarana Informatika, Jakarta, Indonesia \\ www.bsi.ac.id \\ dahlia.dls@bsi.ac.id ${ }^{3}$,denynov.dov@bsi.ac.id ${ }^{4}$
}

\begin{abstract}
Abstrak
Setiap pegawai tentunya selalu berusaha meningkatkan kemampuan dan prestasinya. Sehingga dia bisa mendapatkan jenjang karir yang bagus sesuai idamannya. Kelembagaan Direktorat Jenderal Minyak dan Gas Bumi dalam Kementerian ESDM sebagaimana dalam hal Penilaian kinerja pegawai juga diberikan perusahaan dalam rangka memberikan penghargaan atas prestasi tertentu. Pada saat ini analisis penilaian Pegawai di Ditjen Migas masih dilakukan secara subyektif. Seharusnya ada cara dan metode sebagai pemimpin pemilihan alternatifyang sesuai dengan kebutuhan. Pada penelitian ini, metode pencocokan profil digunakan sebagai alternatif untuk memberikan penilaian dan evaluasi indeks kinerja utama dari setiap pegawai. Ada dua aspek dalam melakukan penilaian dan evaluasi, yaitu: Aspek Kinerja dan Aspek Kepuasan Kerja. Ada beberapa tingkatan Aspek Kinerja: Kemimpinan ketelitian dan tanggung jawab, verbalisasi ide, dorongan berprestasi, konsentrasi dan imajinasi kreatif. Aspek Kepuasan Kerja memiliki kedisiplinan, nilai moral tinggi, terampil, integritas dan Loyalitas,. Ada perubahan peringkat dari kandidat setelah dihitung dengan metode pencocokan profil yang pegawainya dengan NIP 1388510026 memiliki posisi pertama di 4.5137.
\end{abstract}

Kata kunci: Penilaian Kinerja Pegawai, Profile Matching, Ditjen Migas

\begin{abstract}
Every employee is always trying to improve their skills and achievements. So he can get a good career path according to his idea. Institutional Directorate General of Oil and Gas in the Ministry of ENERGY and Mineral resources, as well as the assessment of employee performance also provided by the company to reward certain achievements. At this time analysis of assessment officers in Ditjen Migas is still done in a subjective. There should be ways and methods as an alternative election leader to suit your needs. In this study, the profile matching method was used as an alternative to providing assessment and evaluation of the key performance indexes of each employee. There are two aspects in conducting assessment and evaluation, namely: performance aspect and work satisfaction aspect. There are several levels of performance aspects: a leadership of thoroughness and responsibility, verbalization of ideas, encouragement of achievement, concentration, and creative imagination. The work satisfaction aspect has a discipline, high moral value, skilled, integrity, and loyalty. There is a ranking change from candidates after being counted by the profile matching method whose employees with NIP 1388510026 have the first position in 4.5137 .
\end{abstract}

Keywords: Employee Performance Assessment, Profile Matching, DG Oil and Gas

\section{INTRODUCTION}

Every employee in Ditjen Migas always strives to improve its capabilities and achievements. So he can get a good career path according to his idea. The reliable and supporting development in Ditjen Migas will certainly make it easy for people to get higher performance 
assessment results from previous positions. Employee performance assessment was also given by the Directorate of Oil and Gas to reward certain achievements. At this time analysis of officers assessment in Ditjen Migas is still conducted in a subjective (Mashyur \& Frieyadie, 2019), If the coworker or employer performs an assessment subjectively (Handayani, 2017), Employees who are assessed will not have the same value as both (Chasanah et al., 2012).

The research that will be discussed in this research is how to assess employees by the criteria based on objective consideration between the competencies, qualifications, and requirements required by the Directorate General of Oil and gas without distinguishing gender, ethnic, religious, racial and (Astriratma et al., 2017) which covers aspects of performance and work satisfaction aspect in a particular position, to assist the assessment process of this employee's performance, need to create a system that can provide input for management, especially General Bureau and personnel in making the right decision for the development of potential employees (Purwaningsih \& Supriyanto, 2020)

To facilitate the implementation of the assessment process of personnel performance from each employee, a decision-making system is aimed at facilitating the process. One of the methods used in decision assessing employee performance is Profile Matching. Matching profile matching is a decision-making mechanism by assuming a variable predictor is ideal to be owned by the employee, instead of the minimum level that must be filled or passed (Ernawati et al., 2017). Because Profile Matching method can identify the employees who have good or bad performance (Handayani, 2017) and provide maximum results, valid data, and efficient time. The criteria or aspects used in the decision support system for CIVIL servants in this achievement are disciplines, integrity, organizational commitment, leadership, cooperation, job achievement and service-oriented (Kristiana, 2015).

\section{RESEARCH METHODS}

Obtain data by conducting research directly to obtain good and correct data with the following data collection model :

a. Observation

In this method, the author performs a direct observation (observation) which is one of the techniques of collecting data that is effective enough to study a system. The author performs observations that are the process of assessment of employees ' performance and detailed research directly on the Directorate General of Oil and gas.

b. Interview

In this method, interview with questions and answers directly with the head of Data Manager Sub-section and Information Directorate General of Oil, Mr. Agustiawan, about any indicator that is a reference to the assessment of employee performance.

c. Library Studies

By this method, the author describes the problem clearly and objectively based on the theories that the authors learned during the lecture. Besides, authors also get data through the collection of multiple books, journals, searching Google or ebook.

\section{Types of Research}

The study uses quantitative approaches as well as including applied research.

\section{Target/Subject Research}

The Target/subject in this research is to assist the HRD in conducting an assessment of employee performance of the Directorate General of Oil and gas using the Profile Matching method..

\section{RESEARCH METHODOLOGY}

Research or research is often described as an investigative, orderly and systematic investigation process aimed at discovering, interpreting, and revising facts.

\section{Stages of Research}

By the description of the research above that the research activities are conducted with a planned, orderly and systematic. For that, research activities are carried out in several phases.

1. Literature Survey

In this early stage, researchers conducted a collection of literature materials and related information.

2. Problem Identification

Continuing the research by identifying the problems that will be discussed, about the decision support system of employee performance assessment using the Profile Matching Method of Directorate General of Oil and gas. Based on the literature and information obtained.

3. Library Studies

Researchers study literature in the form of theoretical books on decision support systems 
and Profile Matching methods that will be used as theoretical studies in research.

4. Hypothesis
a. Does the influence of subjective employee performance assessment become more objective?
b. There is more effective influence by using Profile Matching method in determining the assessment of employee's performance?

In this research, the error rate (acceptable error) used is $10 \%$. From the results obtained in the calculation above, there is a minimum sample of 4.76 and sampled as many as 5 employees.

\section{RESULTS OF RESEARCH AND DISCUSSION}

\section{Aspects of Employee Performance Assessment}

In the assessment of employee performance, using Profile Matching method, there are several aspects assessed and from this aspect, there are sub-criteria, which is can be seen in Table 1 as follows :

Table 1 Aspects of Performance Assessment

1. Performance Aspects
a. Leadership, Transparency, and
b. Responsibility
c. Boost Achievement
d. Concentration
e. Creative Imagination

\begin{tabular}{ll} 
2. Job Satisfaction Aspect \\
\hline a. Discipline \\
b. High Moral Value \\
c. Skilled \\
d. Integrity \\
e. Loyalty
\end{tabular}

Here are the sub-criteria values found in table 2 :

Table 2 Range Values

\begin{tabular}{ccc}
\hline \multicolumn{3}{c}{ Sub Criteria Value } \\
\hline Range & Great Values & Scale \\
\hline$<64$ & 1 & Less \\
$65-74$ & 2 & Enough \\
$75-84$ & 3 & Good enough \\
$85-94$ & 4 & Good \\
$95-100$ & 5 & Excellent \\
\hline
\end{tabular}

Calculation of Employee Performance Assessment with Profile Matching Method

\section{Competency GAP Mapping}

Before calculating the value of competency Gap from all candidate officers who will be in the performance value, in table 3 below are a table of values of performance aspects and aspects of work satisfaction.

Table 3 Performance Aspect Values Table

\begin{tabular}{|c|c|c|c|c|c|c|}
\hline \multirow{3}{*}{$\begin{array}{c}N \\
0\end{array}$} & \multirow{3}{*}{ NIK } & \multicolumn{5}{|c|}{ Performance } \\
\hline & & KN & $\mathrm{KN}$ & $\mathrm{KN}$ & $\mathrm{KN}$ & $\mathrm{KN}$ \\
\hline & & 01 & 02 & 03 & 04 & 05 \\
\hline 1 & $\begin{array}{l}\text { NIK.197903082008 } \\
011001\end{array}$ & 87 & 85 & 81 & 78 & 84 \\
\hline 2 & $\begin{array}{l}\text { NIK.198707102015 } \\
032005\end{array}$ & 83 & 82 & 79 & 88 & 90 \\
\hline 3 & $\begin{array}{l}\text { NIK.199702022019 } \\
021002\end{array}$ & 91 & 86 & 84 & 87 & 85 \\
\hline 4 & $\begin{array}{l}\text { NIK.199311192019 } \\
021001\end{array}$ & 90 & 82 & 78 & 88 & 80 \\
\hline 5 & $\begin{array}{l}\text { NIK.196806021990 } \\
032001\end{array}$ & 82 & 78 & 87 & 95 & 77 \\
\hline
\end{tabular}

Description :

KN01 : Leadership, Thoroughness, and Responsibility

KN02 : Verbalization of Ideas

KN03 : Boost Achievement

KN04 : Concentration

KN05 : Creative Imagination

It can be seen that each NIK gets its value each according to its performance aspects.

Table 4 Table of Work Satisfaction Aspect Value

\begin{tabular}{|c|c|c|c|c|c|c|}
\hline \multirow{3}{*}{ No } & \multirow{3}{*}{ NIK } & \multicolumn{5}{|c|}{ Job Satisfaction } \\
\hline & & KK & KK & KK & KK & KK \\
\hline & & 01 & 02 & 03 & 04 & 05 \\
\hline 1 & $\begin{array}{l}\text { NIK.197903082008 } \\
011001\end{array}$ & 82 & 75 & 86 & 89 & 89 \\
\hline 2 & $\begin{array}{l}\text { NIK.198707102015 } \\
032005\end{array}$ & 83 & 87 & 84 & 79 & 84 \\
\hline 3 & $\begin{array}{l}\text { NIK.199702022019 } \\
021002\end{array}$ & 81 & 83 & 78 & 75 & 83 \\
\hline 4 & $\begin{array}{l}\text { NIK.199311192019 } \\
021001\end{array}$ & 86 & 82 & 85 & 81 & 85 \\
\hline 5 & $\begin{array}{l}\text { NIK.196806021990 } \\
032001\end{array}$ & 84 & 84 & 81 & 82 & 85 \\
\hline
\end{tabular}

Description :

KK01 : Discipline

KK02 : High Moral Value

KK03 : Skilled

KK04 : Integrity

KK05 : Loyalty

It is explained that each NIK gets its value according to its performance aspects. 


\section{Mapping Gap Competency Performance Aspect in Directorate General of Oil and Gas}

The meaning of the gap here is the difference between the coordinator profile and the employee profile. The calculation of competency gap mapping is based on the aspects that exist, here are the calculations in Table 5.

Table 5 Gap Performance Aspect

\begin{tabular}{|c|c|c|c|c|c|c|}
\hline \multirow{3}{*}{$\begin{array}{l}\mathrm{N} \\
\mathrm{o}\end{array}$} & \multirow{3}{*}{ NIK } & \multicolumn{5}{|c|}{ Performance } \\
\hline & & $\mathrm{KN}$ & $\mathrm{KN}$ & $\mathrm{KN}$ & KN & $\mathrm{KN}$ \\
\hline & & 01 & 02 & 03 & 04 & 05 \\
\hline 1 & $\begin{array}{l}\text { NIK.197903082008 } \\
011001\end{array}$ & 4 & 4 & 3 & 3 & 3 \\
\hline 2 & $\begin{array}{l}\text { NIK.198707102015 } \\
032005\end{array}$ & 3 & 3 & 3 & 4 & 5 \\
\hline 3 & $\begin{array}{l}\text { NIK.199702022019 } \\
021002\end{array}$ & 4 & 4 & 3 & 4 & 4 \\
\hline 4 & $\begin{array}{l}\text { NIK.199311192019 } \\
021001\end{array}$ & 4 & 3 & 3 & 4 & 3 \\
\hline 5 & $\begin{array}{l}\text { NIK.196806021990 } \\
032001\end{array}$ & 3 & 3 & 4 & 5 & 3 \\
\hline & Profile Coordinator & 4 & 3 & 3 & 3 & 5 \\
\hline 1 & $\begin{array}{l}\text { NIK.197903082008 } \\
011001\end{array}$ & 0 & 1 & 0 & 0 & -2 \\
\hline 2 & $\begin{array}{l}\text { NIK.198707102015 } \\
032005\end{array}$ & -1 & 0 & 0 & 1 & 0 \\
\hline 3 & $\begin{array}{l}\text { NIK.199702022019 } \\
021002\end{array}$ & 0 & 1 & 0 & 1 & -1 \\
\hline 4 & $\begin{array}{l}\text { NIK.199311192019 } \\
021001\end{array}$ & 0 & 0 & 0 & 1 & -2 \\
\hline 5 & $\begin{array}{l}\text { NIK.196806021990 } \\
032001\end{array}$ & -1 & 0 & 1 & 2 & -2 \\
\hline
\end{tabular}

Based on the results of the performance aspect calculation of table 5 can be known Gap or the difference from the profile required for each candidate.

\section{Mapping Gap Competency of Work Satisfaction Aspect of Ditjen Migas}

Table 6 Gap Work Satisfaction Aspect

\begin{tabular}{|c|c|c|c|c|c|c|}
\hline \multirow{3}{*}{$\begin{array}{l}N \\
0\end{array}$} & \multirow{3}{*}{ NIK } & \multicolumn{5}{|c|}{ Job Satisfaction } \\
\hline & & KK0 & KK0 & KK0 & KK0 & KK0 \\
\hline & & 1 & 2 & 3 & 4 & 5 \\
\hline 1 & $\begin{array}{l}\text { NIK.1979030820080 } \\
11001\end{array}$ & 3 & 3 & 4 & 4 & 4 \\
\hline 2 & $\begin{array}{l}\text { NIK.1987071020150 } \\
32005\end{array}$ & 3 & 4 & 3 & 3 & 3 \\
\hline 3 & $\begin{array}{l}\text { NIK.1997020220190 } \\
21002\end{array}$ & 3 & 3 & 3 & 3 & 3 \\
\hline 4 & $\begin{array}{l}\text { NIK.1993111920190 } \\
21001\end{array}$ & 4 & 3 & 4 & 3 & 4 \\
\hline 5 & $\begin{array}{l}\text { NIK.1968060219900 } \\
32001\end{array}$ & 3 & 3 & 3 & 3 & 4 \\
\hline & Profile Coordinator & 4 & 3 & 3 & 3 & 5 \\
\hline 1 & $\begin{array}{l}\text { NIK.1979030820080 } \\
11001\end{array}$ & -1 & 0 & 1 & 1 & -1 \\
\hline
\end{tabular}

\begin{tabular}{|c|c|c|c|c|c|c|}
\hline \multirow{3}{*}{$\begin{array}{l}\mathrm{N} \\
\mathrm{o}\end{array}$} & \multirow{3}{*}{ NIK } & \multicolumn{5}{|c|}{ Job Satisfaction } \\
\hline & & KK0 & KK0 & KK0 & KK0 & KK0 \\
\hline & & 1 & 2 & 3 & 4 & 5 \\
\hline 2 & $\begin{array}{l}\text { NIK.1987071020150 } \\
32005\end{array}$ & 0 & 1 & 0 & 0 & -2 \\
\hline 3 & $\begin{array}{l}\text { NIK.1997020220190 } \\
21002\end{array}$ & -1 & 0 & 0 & 0 & -2 \\
\hline 4 & $\begin{array}{l}\text { NIK.1993111920190 } \\
21001\end{array}$ & -1 & 0 & 1 & 0 & -1 \\
\hline & NIK.1968060219900 & & & & & \\
\hline 5 & 32001 & -1 & 0 & 0 & 0 & -1 \\
\hline
\end{tabular}

\section{Determination of Gap Value Weights}

Weighting is done after the gap is obtained at each employee, each employee profile is weighted by the value of the table weight of the gap value.

Determination of Weight GAP Value of Performance Aspect of Directorate General of Oil and Gas

After obtaining the gap in each officer, each employee's profile is weighted by the value based on the table weight of the gap value that can be seen in the table. 7. The following is the determination of weights in the employee performance assessment :

Table 7 Weight Performance Aspect Value

\begin{tabular}{|c|c|c|c|c|c|c|}
\hline \multirow{2}{*}{$\begin{array}{l}\mathrm{N} \\
\mathrm{o}\end{array}$} & \multirow[b]{2}{*}{ NIK } & \multicolumn{5}{|c|}{ Performance } \\
\hline & & $\begin{array}{l}\mathrm{KN} \\
01\end{array}$ & $\begin{array}{l}\mathrm{KN} \\
02\end{array}$ & $\begin{array}{l}\mathrm{KN} \\
03\end{array}$ & $\begin{array}{l}\mathrm{KN} \\
04\end{array}$ & $\begin{array}{l}\mathrm{KN} \\
05\end{array}$ \\
\hline 1 & $\begin{array}{l}\text { NIK.197903082008 } \\
011001\end{array}$ & 0 & 1 & 0 & 0 & -2 \\
\hline 2 & $\begin{array}{l}\text { NIK.198707102015 } \\
032005\end{array}$ & -1 & 0 & 0 & 1 & 0 \\
\hline 3 & $\begin{array}{l}\text { NIK.199702022019 } \\
021002\end{array}$ & 0 & 1 & 0 & 1 & -1 \\
\hline 4 & $\begin{array}{l}\text { NIK.199311192019 } \\
021001\end{array}$ & 0 & 0 & 0 & 1 & -2 \\
\hline 5 & $\begin{array}{l}\text { NIK.196806021990 } \\
032001\end{array}$ & -1 & 0 & 1 & 2 & -2 \\
\hline 1 & $\begin{array}{l}\text { NIK.197903082008 } \\
011001\end{array}$ & 5 & 4,5 & 5 & 5 & 3 \\
\hline 2 & $\begin{array}{l}\text { NIK.198707102015 } \\
032005\end{array}$ & 4 & 5 & 5 & 4,5 & 5 \\
\hline 3 & $\begin{array}{l}\text { NIK.199702022019 } \\
021002\end{array}$ & 5 & 4,5 & 5 & 4,5 & 4 \\
\hline 4 & $\begin{array}{l}\text { NIK.199311192019 } \\
021001\end{array}$ & 5 & 5 & 5 & 4,5 & 3 \\
\hline 5 & $\begin{array}{l}\text { NIK.196806021990 } \\
032001\end{array}$ & 4 & 5 & 4,5 & 3,5 & 3 \\
\hline
\end{tabular}

Based on the calculation results in table 7 , the weight of the performance aspect value for each candidate.

\section{Determination of Weight GAP Value of Work Satisfaction Aspect of Ditjen Migas}

Weighting is done after the gap is obtained at each employee, each employee profile is weighted by the value of the table weight of the gap value. 
JURNAL RISET INFORMATIKA

Vol. 2, No. 2 March 2020
P-ISSN: 2656-1743 |E-ISSN: 2656-1735

DOI: https://doi.org/10.34288/jri.v2i2.130
Table 8 Weight Work Satisfaction Aspect Value

\begin{tabular}{|c|c|c|c|c|c|c|}
\hline \multirow{3}{*}{ No } & \multirow{3}{*}{ NIK } & \multicolumn{5}{|c|}{ Job Satisfaction } \\
\hline & & KK & KK & KK & KK & KK \\
\hline & & 01 & 02 & 03 & 04 & 05 \\
\hline 1 & $\begin{array}{l}\text { NIK.19790308200 } \\
8011001\end{array}$ & -1 & 0 & 1 & 1 & -1 \\
\hline 2 & $\begin{array}{l}\text { NIK.19870710201 } \\
5032005\end{array}$ & 0 & 1 & 0 & 0 & -2 \\
\hline 3 & $\begin{array}{l}\text { NIK.19970202201 } \\
9021002\end{array}$ & -1 & 0 & 0 & 0 & -2 \\
\hline 4 & $\begin{array}{l}\text { NIK.19931119201 } \\
9021001\end{array}$ & -1 & 0 & 1 & 0 & -1 \\
\hline 5 & $\begin{array}{l}\text { NIK.19680602199 } \\
0032001\end{array}$ & -1 & 0 & 0 & 0 & -1 \\
\hline 1 & $\begin{array}{l}\text { NIK.19790308200 } \\
8011001\end{array}$ & 4 & 5 & 4.5 & 4.5 & 4 \\
\hline 2 & $\begin{array}{l}\text { NIK.19870710201 } \\
5032005\end{array}$ & 5 & 4.5 & 5 & 5 & 3 \\
\hline 3 & $\begin{array}{l}\text { NIK.19970202201 } \\
9021002\end{array}$ & 4 & 5 & 5 & 5 & 3 \\
\hline 4 & $\begin{array}{l}\text { NIK.19931119201 } \\
9021001\end{array}$ & 4 & 5 & 4.5 & 5 & 4 \\
\hline 5 & $\begin{array}{l}\text { NIK.19680602199 } \\
0032001\end{array}$ & 4 & 5 & 5 & 5 & 4 \\
\hline
\end{tabular}

Based on the results of the calculation in Table 5 , the weight of the work satisfaction aspect value for each candidate.

\section{Calculations and Grouping Core Factor and Secondary Facto}

After determining the weight of the gap value for each aspect of the employee performance assessment, then each aspect is divided into two namely core factor and secondary factor. Here is the calculation:

\section{Core Factor Value and Secondary Factor Performance Aspect}

Core Factor obtained from 3 main subcriteria, namely KNO1, KNO2, KNO3, and Secondary Factor obtained from 2 sub-criteria namely KNO4 and KN05. Then the Core Factor and Secondary Factor values are calculated according to the formula and the result can be seen in table 9. Here's how the calculation :

$$
\mathrm{NCF}: \frac{\sum \mathrm{NC}(\mathrm{kn} 1 \mathrm{kn} 2, \mathrm{kn} 3)}{\sum \mathrm{IC}}
$$

The results obtained:
1. $\mathrm{NCF}=4,83$
2. $\mathrm{NCF}=4,66$
3. $\mathrm{NCF}=4,83$
4. $\mathrm{NCF}=5$
5. $\mathrm{NCF}=4,5$

$\mathrm{NSF}: \frac{\sum \mathrm{NS}(\mathrm{kn} 1, \mathrm{kn} 2)}{\sum \mathrm{IS}}$

The results obtained:
1. $\quad \mathrm{NSF}=4$
2. $\mathrm{NSF}=4,75$
3. $\mathrm{NSF}=4,25$
4. $\mathrm{NSF}=3,75$
5. $\mathrm{NSF}=3,25$

Description :

NCF : The Mean Value of Core Factor

NC : Total Core Factor Value

IC : Number of Core Factor Items

NSF : Average Secondary Factor Value

NS : Total Number of Secondary Factor Values

IS : Number of Items Secondary Factor

Table 9 Values CF and SF Performance Aspects

\begin{tabular}{ccccccccc}
\hline \multirow{2}{*}{ No } & \multirow{2}{*}{ NIK } & \multicolumn{9}{c}{ Variabel } \\
\cline { 3 - 9 } & & KN01 & KN02 & KN03 & KN04 & KN05 & CF & SF \\
\hline 1 & NIK.197903082008011001 & 5 & 4,5 & 5 & 5 & 3 & 4,83 & 4 \\
\hline 2 & NIK.198707102015032005 & 4 & 5 & 5 & 4,5 & 5 & 4,66 & 4,75 \\
\hline 3 & NIK.199702022019021002 & 5 & 4,5 & 5 & 4,5 & 4 & 4,83 & 4,25 \\
\hline 4 & NIK.199311192019021001 & 5 & 5 & 5 & 4,5 & 3 & 5 & 3,75 \\
\hline 5 & NIK.196806021990032001 & 4 & 5 & 4,5 & 3,5 & 3 & 4,5 & 3,25 \\
\hline
\end{tabular}

Based on the calculation result of Core Factor and Secondary Factor for the performance aspect obtained value for each candidate in table 9 .

\section{Core Factor and Secondary Factor Value for Job Satisfaction Aspect}

Core Factor obtained from 3 main subcriteria, namely KK01, KK02, KK03 and Secondary Factor obtained from the two remaining subcriteria are KK04 and KK05. Then the Core Factor and Secondary Factor values are calculated according to the formula and the result can be seen in table 10. Here's how the calculation:

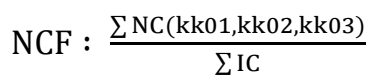

The results obtained:
1. $\mathrm{NCF}=4,5$
2. $\mathrm{NCF}=4,5$
3. $\mathrm{NCF}=4,66$
4. $\mathrm{NCF}=4,833$
5. $\mathrm{NCF}=4,66$ 
$\mathrm{NSF}: \frac{\sum \mathrm{NS}(\mathrm{kk} 04, \mathrm{kk} 05)}{\sum \mathrm{IS}}$

The results obtained:

1. $\mathrm{NSF}=4,25$

2. $\mathrm{NSF}=4$

3. $\mathrm{NSF}=4$

4. $\mathrm{NSF}=4,5$

5. $\mathrm{NSF}=4,5$
Description :

NCF : The mean value of Core Factor

NC : Total Core Factor value

IC : Number of Core Factor items

NSF : Average Secondary Factor value

NS : Total number of Secondary Factor values

IS : Number of items Secondary Factor

Table 10 Value CF and SF Work Satisfaction Aspect

\begin{tabular}{|c|c|c|c|c|c|c|c|c|}
\hline \multirow{2}{*}{ No } & \multirow{2}{*}{ NIK } & \multicolumn{7}{|c|}{ Variable } \\
\hline & & KK01 & KK02 & KK03 & KK04 & KK05 & $\mathrm{CF}$ & SF \\
\hline 1 & NIK.197903082008011001 & 4 & 4 & 4 & 4 & 4 & 4,5 & 4,25 \\
\hline 2 & NIK.198707102015032005 & 5 & 5 & 4 & 4 & 5 & 4,5 & 4 \\
\hline 3 & NIK.199702022019021002 & 4 & 4 & 4 & 4 & 4 & 4,66 & 4 \\
\hline 4 & NIK.199311192019021001 & 4 & 4 & 5 & 4 & 4 & 4,83 & 4,5 \\
\hline 5 & NIK.196806021990032001 & 4 & 4 & 4 & 4 & 5 & 4,66 & 4,5 \\
\hline
\end{tabular}

Based on the calculation result of Core Factor and Secondary Factor for work satisfaction aspect obtained value for each candidate in table 10 .

\section{Total Value Calculation}

From the calculation of the core factor and secondary factor of each aspect, then the calculation of the total value. Calculations can be seen with the formula below :

$\mathrm{N}(\mathrm{kn}, \mathrm{kk})=$

$(\mathrm{x}) \% \mathrm{NCF}(\mathrm{kn}, \mathrm{kk})+(\mathrm{x}) \% \mathrm{NSF}(\mathrm{kn}, \mathrm{kk})=\mathrm{N}(\mathrm{kn}, \mathrm{kk})$

Calculation of Total Aspect Value of Performance

Based on the formula of total value calculation above we can calculate the total value of each aspect. Here is a calculation of the performance aspect :

$\mathrm{N}(\mathrm{kn})=(\mathrm{x}) \% \mathrm{NCF}(\mathrm{kn}, \mathrm{kk})+(\mathrm{x}) \% \mathrm{NSF}(\mathrm{kn}, \mathrm{kk})=$

$\mathrm{N}(\mathrm{kn}, \mathrm{kk})$

The results obtained:

1. $\mathrm{N}(\mathrm{kn})=4,6225$

2. $\mathrm{N}(\mathrm{kn})=4,6825$

3. $N(\mathrm{kn})=4,6875$

4. $\mathrm{N}(\mathrm{kn})=4,687$

5. $\mathrm{N}(\mathrm{kn})=4,1875$

Table 11 Performance aspects Total Value

\begin{tabular}{ccccc}
\hline \multirow{2}{*}{ No } & \multirow{2}{*}{ NIK } & \multicolumn{3}{c}{ Variable } \\
\cline { 3 - 5 } & & CF & SF & N(kn) \\
\hline 1 & NIK.197903082008011001 & 4,83 & 4 & 4,6225 \\
2 & NIK.198707102015032005 & 4,66 & 4,75 & 4,6825 \\
3 & NIK.199702022019021002 & 4,83 & 4,25 & 4,6875 \\
4 & NIK.199311192019021001 & 5 & 3,75 & 4,6875 \\
5 & NIK.196806021990032001 & 4,5 & 3,25 & 4,1875 \\
\hline
\end{tabular}

Based on the total value of the performance aspects, the total value for each candidate is based on table 11 .

Total Value Calculation Aspects of Job Satisfaction

Based on the formula of total value calculation above we can calculate the total value of each aspect. Here is the calculation of the work satisfaction aspect

$$
\begin{aligned}
& \mathrm{N}(\mathrm{kk})=(\mathrm{x}) \% \mathrm{NCF}(\mathrm{kn}, \mathrm{kk})+(\mathrm{x}) \% \mathrm{NSF}(\mathrm{kn}, \mathrm{kk})= \\
& \mathrm{N}(\mathrm{kn}, \mathrm{kk})
\end{aligned}
$$

The results obtained:

1. $\mathrm{N}(\mathrm{kk})=4,4375$

2. $\mathrm{N}(\mathrm{kk})=4,375$

3. $\mathrm{N}(\mathrm{kk})=4,5$

4. $\mathrm{N}(\mathrm{kk})=4,75$

5. $\mathrm{N}(\mathrm{kk})=4,625$

Table 12 Total Value Aspects of Work Satisfaction

\begin{tabular}{ccccc}
\hline \multirow{2}{*}{ No } & \multirow{2}{*}{ NIK } & \multicolumn{3}{c}{ Variable } \\
\cline { 3 - 5 } & & $\mathrm{CF}$ & $\mathrm{SF}$ & $\mathrm{N}(\mathrm{kk})$ \\
\hline 1 & NIK.197903082008011001 & 4,5 & 4,25 & 4,4375 \\
2 & NIK.198707102015032005 & 4,5 & 4 & 4,375 \\
3 & NIK.199702022019021002 & 4,66 & 4 & 4,5 \\
4 & NIK.199311192019021001 & 4,83 & 4,5 & 4,75 \\
5 & NIK.196806021990032001 & 4,66 & 4,5 & 4,625 \\
\hline
\end{tabular}

Based on calculating the total value of work satisfaction aspects, the total value for each candidate is based on table 12 .

\section{Ranking Calculation}

Ranking in Profile Matching method is the final result of determining the performance assessment of the employees of the Directorate General of Oil and gas. Ranking calculations can be calculated based on the formula below : 
Ranking $=(\mathrm{x}) \% \mathrm{~N}(\mathrm{kn})+(\mathrm{x}) \% \mathrm{~N}(\mathrm{kk})$

Description :

$\mathrm{N}(\mathrm{kn})$ : Performance value

$\mathrm{N}(\mathrm{kk}) \quad$ : Work Satisfaction value

$(\mathrm{x}) \% \quad$ : Percent Value inputted
The following are the results of ranking calculations in the selection of a coordinator:

1 Ranking $=4,57813$

2 Ranking $=4,60563$

3 Ranking $=4,64063$

4 Ranking $=4,70313$

5 Ranking $=4,2968$

Table 13 Ranking

\begin{tabular}{cccccc}
\hline & NIK & $\mathrm{N}(\mathrm{kn})$ & $\mathrm{N}(\mathrm{kk})$ & Score & Ranking \\
\hline 1 & NIK.197903082008011001 & 4.625 & 4.4375 & 4.57813 & 4 \\
\hline 2 & NIK.198707102015032005 & 4.6825 & 4.375 & 4.60563 & 3 \\
\hline 3 & NIK.199702022019021002 & 4.6875 & 4.5 & 4.64063 & 2 \\
\hline 4 & NIK.199311192019021001 & 4.6875 & 4.75 & 4.70313 & 1 \\
\hline 5 & NIK.196806021990032001 & 4.1875 & 4.625 & 4.29688 & 5 \\
\hline
\end{tabular}

Based on the ranking calculations for each candidate, the score is obtained for each candidate based on table 13 .

\section{Research Results}

The last result of this study was the election of five people with the top rankings. In the 5th stage is occupied by employees with NIK. 196806021990032001 , in the 4th stage occupied by officers with NIK. 197903082008011001, in the 3rd rank occupied by officers with NIK. 198707102015032005, in the 2nd rank occupied by officers with NIK. 199702022019021002, and in the first stage occupied by the officers with NIK. 199311192019021001.

Score results can be seen in Figure 1 of the chart below :

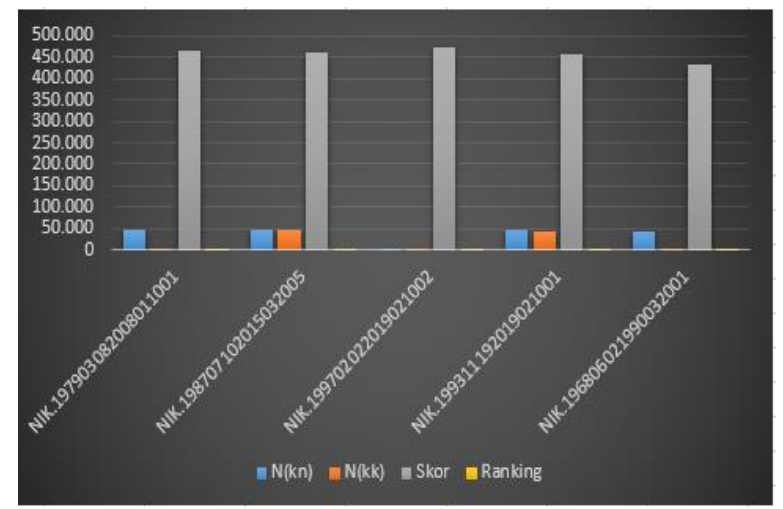

Figure 1. Charts Final Research Results

\section{CONCLUSION AND SUGGESTION}

\section{Conclusion}

Based on the discussion of the assessment of the performance assessments of the Directorate General of Oil and gas by using the Profile
Matching method, the conclusion that can be taken from the research in the process of determining the ranking of employees calculated using the Profile Matching method begins with determining the GAP, the weight of Gap value, grouping core factor and secondary factor, calculation of total value, and last ranking. From the research results, which are seen from aspects of performance and aspects of working culture, along with other criteria and using the Profile Matching method, employees with NIK. 199311192019021001. Get the first rank and have the chance to go up and get rewarded. Thus to get the performance results of an employee is not only seen from one criterion but also must have good performance and satisfaction work.

\section{Suggestion}

From the results of the research that has been done by the authors, then it can be proposed some advice, including for further research will be made program of decision support system in a larger scope as in the form of Web or Android. Preferably in the process of assessment of employee performance, all employees are included so that all employees are increasingly active in working to be elected to get a hike.

\section{REFERENCE LIST}

Astriratma, R., Wardoyo, R., \& Musdholifah, A. (2017). SPK Rekomendasi Pemilihan Kandidat Pejabat Struktural Menggunakan Metode Profile Matching (Studi Kasus: Pemerintah Kota Tarakan). IJCCS (Indonesian Journal of Computing and Cybernetics Systems), $11(1), \quad 77$. https://doi.org/10.22146/ijccs.17342 
Chasanah, T. D., Effendi, U., \& Silalahi, R. L. R. (2012). Penilaian Kinerja Karyawan Bagian Personalia Berdasarkan Kompetensi dengan Metode 360 Derajat (Studi Kasus di PG. Kebon Agung - Malang). Jurnal Industria, 4(1), 31-40.

Ernawati, E., Hidayah, N. A., \& Fetrina, E. (2017). RANCANG BANGUN SISTEM PENDUKUNG KEPUTUSAN KENAIKAN JABATAN PEGAWAI DENGAN METODE PROFILE MATCHING (Studi Kasus: Kementerian Agama Kantor Wilayah DKI Jakarta). Studia Informatika: Jurnal Sistem Informasi, 10(2), 127-134. https://doi.org/10.15408/SIJSI.V10I2.7760

Handayani, R. I. (2017). SISTEM PENDUKUNG KEPUTUSAN PEMILIHAN KARYAWAN BERPRESTASI DENGAN METODE PROFILE MATCHING PADA PT. SARANA INTI PERSADA (SIP). Jurnal Pilar Nusa Mandiri, 13(1), 28-34. https://doi.org/10.33480/PILAR.V13I1.11
Kristiana, T. (2015). Penerapan Profile Matching untuk Penilaian Kinerja Pegawai Negeri Sipil (PNS). Jurnal Pilar Nusa Mandiri, XI(2), 161170.

Mashyur, R. S., \& Frieyadie, F. (2019). PENGGUNAAN METODE PROFILE MATCHING UNTUK PEMILIHAN EOSH CAPTAIN TERBAIK PADA PT.COCA-COLA INDONESIA. Jurnal Pilar Nusa Mandiri, 15(2), 235-240.

https://doi.org/10.33480/pilar.v15i2.767

Purwaningsih, Y., \& Supriyanto, R. (2020). SISTEM PENDUKUNG KEPUTUSAN PROMOSI PEJABAT STRUKTURAL MELALUI DIKLAT KEPEMIMPINAN IV MENGGUNAKAN METODE PROFILE MATCHING STUDI KASUS DI PPPPTK BAHASA JAKARTA: Jurnal Aplikasi Bisnis Dan Manajemen (JABM), 6(1), 74-74. https://doi.org/10.17358/JABM.6.1.74 